УДК $82.091 \ll 652 »$

Давиденко I. О., кандидат філологічних наук, доцент кафедри зарубіжної літератури та теорії літератури Бердянського державного педагогічного університету

\title{
СМИСЛОВІ ДОМННАНТИ ЗАГОЛОВКІВ ЄВРОПЕЙСЬКОЇ ОВІДІАНИ ДРУГОЇ ПОЛОВИНИ ХХ СТОЛІТТЯ
}

\footnotetext{
Стаття присвячена дослідженню особливостей поетики заголовків європейськой Овідіани другої половини XX $\mathrm{cm}$. У методологічній матриці порівняльно-типологічного підходу висвітлено основні смислові концепти назв романів «Овідій Назон - поет» Яцека Бохенського, «Останній світ» Крістофа Рансмайра, "Скандал в імператорському сімействі» Валентина Чемериса, а також повісті «Літній птах на зимовому березі» Юрія Мушкетика. За результатами компаративного аналізу текстуальної бази послідовно
} 
доведено правомірність визначення заголовка, як ключа, до першого інтуїтивнопролептичного тлумачення твору.

Ключові слова: автор, античний, заголовок, інтерпретація, Овідій, порівняльне літературознавство, роман, текст.

The article deals with titles' specification in the texts of European Ovidiana of the second half of the $20^{\text {th }}$ century. The problem is relatively fresh in literary criticism and needs a new study. On the basis of comparative typological approach the implicit meaning of headings "Naso the Poet» by Jacek Bochenski, "The Last World» by Christoph Ransmayr, "Scandal in the Emperor's Family» by Valentin Chemeris and «The Summer Swam on the Winter Shore» by Juriy Mushketyk has been exposed. The expansion of literary sources allowed the researcher to reasonably prove the title's determination as a key to a first presentative interpretation of the text.

Key words: ancient, author, comparative literature, interpretation, novel, Ovid, text, title.

Статья посвящена исследованию особенностей поэтики заглавий европейской Овидианы второй половины $X X$ в. $B$ методологической матрице сравнительнотипологического подхода освещены основные смысловые конщепты названий романов «Овидий Назон - поэт» Яиека Бохенского, «Последний мир» Кристофа Рансмайра, «Скандал в императорском семействе» Валентина Чемериса, а также повести «Летняя птица на зимнем берегу» Юрия Мушкетика. Результатами компаративного анализа текстуальной базы последовательно доказано правомерность определения заглавия, как ключа, к первому интуитивно-пролептическому толкованию произведения.

Ключевые слова: автор, античный, заглавие, интерпретация, Овидий, роман, сравнительное литературоведение, текст.

Одним із основних етапів порівняльно-типологічного осягнення феномена авторських візій постаті відомого давньоримського поета Публія Овідія Назона (Publius Ovidius Naso, 43 р. до н. е. - 17 / 18 р. н. е.) є розкриття концептуального змісту заголовків Овідіани, оскільки останні, поряд з іменем письменника, слугують первинним елементом читацької рецепції тексту, а також його інтуїтивно-пролептичного тлумачення. Актуальність нашої студії зумовлена як потребою системного дослідження на різних структурних рівнях інтерпретаційних моделей біографії опального антика, так і відсутністю наукових розробок із репрезентованою проблематикою в українському та зарубіжному літературознавстві.

Мета статті - проаналізувати закодований зміст заголовків європейської Овідіани другої половини XX ст., порівнявши назви творів i основну текстуальну тканину.

Важливість номену у структурній організації твору важко переоцінити: 3 одного боку, він концентрує енергію думки митця, а 3 іншого, - виступає інформативним джерелом і непохитним фундаментом тлумачень реципієнтів. «Книга $i$ є розгорнутий до кінця заголовок», - зазначив із цього приводу 
C. Кржижановський [Кржижановский 2006:7]. Досконале ім'я твору, на переконання А. Шопенгауера, має підпорядковуватися такій формулі: «Бути стислим, лаконічним, влучним $і$ по можливості бути монограмою змісту» [Шопенгауэр 2009:8]. Філософ гостро критикував будь-яку туманність у назвах книг, оскільки вважав, що вона лише вводить в оману читачів.

Роман «Овідій Назон - поет» («Nazo poeta», 1969) Яцека Бохенського має нейтральний заголовок, що складається 3 двох частин: імені головного персонажа та роду його занять. Подібні назви, на думку російської дослідниці Ю. Бабичевої, є складними для аналізу, оскільки імена, виділені в них, стають «умовним знаком певного явищуа, суспільної проблеми. Розпочинаючи читати такий твір, ми заздалегідь налаштовані сприймати та осягати не особливий людський характер $i$ долю, а їх закономірність $i$ обумовленість у певному середовищіi» [Бабичева 2000:63]. Відповідно, змістова валентність назви роману Я. Бохенського обмежена соціально-історичним періодом, до якого належав антик.

Розглядати роки життя поета треба не окремо, а в проекції на так званий «римський мир» (Рax Romana - епоха імператора Августа і його наступників І ст. н. е.), оскільки саме в цей час «шляхом изілеспрямованих $і$ численних реформ Августу і соичіальним верстам, які за ним стояли, вдалося розв'язати багато болючих проблем римського суспільства і держави, щзо так гостро проявилися в часи кривавих громадських війн» [Балух 2005:342]. Політична стабільність, задекларована принципатом, не могла не вплинути на розвиток культури, яка відгукнулася загальним піднесенням мистецтва. В особі сподвижників імператора римська держава почала всебічно підтримувати молоді таланти, надійно заховавши під маскою опіки свою справжню мету - зробити 3 митців носіїв панівної ідеології. «Важливою складовою системи принципату, - слушно зазначає О. Петречко, - стала політична пропаганда. Монети, релігія, архітектура, твори мистецтвва та літератури, навіть законодавство - усе изе було поставлено на службу новій владі, новому режимові як знаряддя пропаганди» [Петречко 2014:23]. Продовжуючи міркування вченого, 
зауважимо, що в літературному середовищі за прямими вказівками імператора працював гурток Мецената, серед відомих членів якого були Вергілій і Горацій.

Водночас, разом із миром і процвітанням, які встановив Август, прийшли зубожіння духовності та деморалізація римської аристократії. Щодо цього особливо цінними видаються свідчення самого Овідія: «Нині направду в нас вік золотий: до посад щуонайвищчих / Золото илях прокладе, золотом купиш любов. / Хоч би в оточенні муз завітав сюди ти, Гомере, - / Як завітаєш ні з чим - вкажуть на двері тобі» («М.», II, 277-280) [Овідій 1999:133]. Римська імперія часів принципату страждала від загальної розбещеності, неробства й переситу, а тому будь-які спроби владної верхівки відновити давні чесноти були марними. Тож є підстави стверджувати, що доба Овідія - амбівалентна: 3 одного боку, панував відносний спокій на кордонах і матеріальний добробут, а 3 іншого, - тотальна деформація моралі, підкріплена культом грошей.

Отже, назва роману польського автора опосередковано вказує, що головним у творі є не лише поет, а й дух часу, носієм якого він був. На це звернула увагу також Х. Заворська, зауваживши, що в тексті Я. Бохенського Овідієві відведено ту саму роль, яку він мав у римському суспільстві: «висхідна зірка нового способу життя, мислення, почуттів» [Zaworska]. Отож, незважаючи на внутрішню корозію, принципат Августа ввійшов в історію як період загального поступу й миру. Тільки за таких умов могли з'явитися легкість, безтурботність та всепоглинаюча тінь Еросу, притаманна поетичному стилеві поета-вигнанця. Саме цю тонку залежність Я. Бохенський утілив у романі «Овідій Назон - поет».

Задуманий спочатку як прозовий переказ «Метаморфоз» Овідія, роман «Останній світ» («Die letzte Welt», 1988) Крістофа Рансмайра набув розголосу ще до появи на полицях книгарень. Цьому посприяла й широка реклама з боку видавця, i загадкова назва твору. «Заголовок, - зазначає М. Барабаш, - як камертон індивідуального письменницького стилю “заряджає” читачаінтерпретатора відповідною духовною енергією автора, настроює на певний лад сприйняття $i$ розуміння авторського задуму, підтексту, надтексту $i$ 
контексту літературного твору» [Челецька 2007:18-19]. Номен «Останній світ», побудований за принципом алегоричного конструкта, - результат матеріалізації стану душевного сум'яття та невизначеності, що охопив австрійське суспільство та загалом Європу в другій половині XX ст. Як слушно зауважила Т. Гундорова, кінець тисячоліття «найконцентрованіше відображає ідею катастрофізму, а ядерний вибух, по суті, символізує у свідомості людей другої половини XX століття кінцесвітню ідею» [Гундорова 2005:13]. Відтак, присутність у тексті «Останнього світу» есхатологічних мотивів $\epsilon$ цілком очікуваною та вмотивованою.

Постмодерністський наратив К. Рансмайра зорієнтований на підготовленого читача, оскільки вже 3 самої назви досить складно зрозуміти (якщо, звичайно, реципієнт не обізнаний із творчим доробком Овідія), що в романі йтиметься про давньоримського класика. Лише підзаголовок «Роман із Овідієвим репертуаром» («Roman mit dem Ovidischen Repertoire»), який, до речі, було випущено в українському перекладі, трохи відкриває завісу задуму письменника. «Перший сигнал, - зазначила з цього приводу Н. Копистянська, автор посилає читачеві, даючи назву твору, підназву, назву розділу тощьо. Письменник спрямовує на певний соиіально-історичний час, створює потрібну йому енергетично-психологічну хвилю очікування, сприйняття зображуваного, дає емоиійний та інтелектуальний старт» [Копистянська 2012:164]. Однак у романі «Останній світ» стрижневою є певна невідповідність між іменем та інтуїтивно очікуваним хронотопом: уже в експозиції стає зрозуміло, що читацькі сподівання на сюжет із античної історії, інспіровані паратекстом, нівелюються авторською концепцією змішування часів. У наративі К. Рансмайра минуле i сучасне переплітаються, утворюючи темпоральну єдність. Крім того, австрійський прозаїк у підзаголовку акцентує увагу не на самій постаті давньоримського класика, а лише на його доробку, використаному як сюжетне тло.

Ідейний зміст, закодований в імені тексту К. Рансмайра, має два рівні розкриття. Перший об’єктивний прочитується як алюзія на «Скорботні елегії» 
Овідія: «А я буду жить на краєчку / Світу й про землю свою снитиму в тій далині» («С.», I, I, 127-128) [Овідій 1999:174]. Очевидно, що йдеться тут про Томи - причорноморську колонію, до якої був засланий антик i в якій відбувається дія роману «Останній світ». Показово, що австрійський прозаїк замість прикметника «крайній» (äußerst) обрав для заголовка його синонім «останній» (letzte). Автор акцентує увагу не на географічній віддаленості об’єкта, а на відсутності іншого подібного простору. Отже, останній, за К. Рансмайром, означає єдиний і унікальний.

Натомість повнота другого рівня смислової наснаженості заголовка роману австрійського майстра осягається лише в процесі безпосереднього читання твору. Ідеться про концептуальний для «Останнього світу» мотив застереження. Крізь текст-палімпсест К. Рансмайра виразно проглядається думка, що в другій половині XX ст. європейська цивілізація дійшла до межі, переступивши яку, вона прирікає себе на вимирання. Відповідно до задуму прозаїка, такою лінією розмежування є ставлення влади до митця й загалом до людини. В інтерпретації К. Рансмайра, трагічна доля Овідія прочитується як алегорія знищення гуманізму, а також свідчення крихкості буття: «I коли Назон справді впав, водяні знаки минущуості почали проступати Котті навіть у камінні. Порівнявши ясний образ часів Сан-Лоренџзо й того чоловіка, щзо в сльозах назавжди покидав одного безхмарного четверга в березні свій дім на n'ящฺиа дель Моро, Котта вперше усвідомив, яка ж легенька - мов пушинкаспоруда ией світ, які вразливі гори, щзо розсипаються на пісок, які нетривкі моря, щзо випаровуються й обертаються в хмари, які короткі спалахи в зірок...» [Рансмайр 1994:64]. Отож світ, зображений К. Рансмайром, - останній, бо в ньому не знаходиться місця для вічних людських ідеалів, бо гроші і влада в ньому заміняють мораль.

Як і попередній автор, Валентин Чемерис використав заголовок-алюзію в романі «Скандал в імператорському сімействі» (1988), підказуючи читачеві, що в центр наративу покладена резонансна подія. Утім, із самої назви досить складно ідентифікувати, про який факт та історичну добу йдеться. Лише в 
пролозі стає зрозуміло, що темпоральний вимір твору окреслений давньоримською реальністю, а саме часом правління Октавіана Августа.

Принципово важливим моментом $є$ те, що В. Чемерис не виніс у заголовок жодного імені героя, зробивши смисловий наголос на події. Метою такого тактичного ходу автора, очевидно, було бажання заінтригувати читача й викликати інтерес до римського минулого. Суть інциденту, якому присвячена розповідь письменника, розкривається впродовж поступового розгортання сюжетної канви. Зауважимо, що скандал у родині імператора репрезентований у романі як кульмінація розвитку конфлікту.

Цей відносно невеликий епізод відіграє концептуальну роль для історичного наративу українського майстра, оскільки, по-перше, є важливим сюжетним вузлом, висвітлюючи жорстокість боротьби за владу, а, по-друге, унаочнює авторську версію причини вигнання Овідія з Рима. Так, згідно із задумом В. Чемериса, імператор Август засудив найвідомішого на той час поета, щоб відвернути увагу громадськості від ганебної поведінки своєї дочки та онуки. Натомість «аморальні» вірші стали лише формальним приводом для винесення вироку опальному митцеві: «Тож конче необхідно було спішно відвести ганьбу від Першого Сімейства. А для изього - покарати точнісінько за таку ж провину, тобто за розпусту, когось, хто був би славетний на увесь Рим. I ияим актом дати зрозуміти: імператорське сімейство, на жаль, не виняток, щ⿻о цуе загальний занепад моралі, тож імператорську дочку й онуку збив на манівці їхній кумир.

А такою славетною $і$ знаною на увесь Рим $i$ всю імперію була лише одна людина - Публій Овідій Назон» [Чемерис 1988:314]. Отже, назва роману В. Чемериса опосередковано вказує на проблемно-тематичну наснаженість твору, а також відіграє роль певного декларативного елемента стосовно гіпотез причин вигнання Овідія.

На відміну від попередніх авторів, концептуальною для назви повісті Юрія Мушкетика стала ідея несумісності та неприродності перебування суб’єкта в певній місцевості. «Літній птах на зимовому березі» (1989) - це 
антитетичний заголовок-алюзія. Протиставляючи теплу пору року холодній, прозаїк таким чином наголошує на характерологічних домінантах, властивих центральним персонажам (Овідію та Поетові XX ст.), а також опосередковано вказує на умови, в які вони були поставлені. Водночас протиставлення «літозима» допомагає реципієнтові визначити певну географічно-кліматичну приналежність героїв. У цьому контексті «літній» означає «лагідний», «ніжний», «м’який», «добрий» (для Овідія таким є Рим, а для Поета - рідне грецьке село на Донеччині). Натомість синонімами лексеми «зимовий»у повісті виступають «суворий», «непривітний», «байдужий» тощо (для Овідія - це Томи, край світу, а для Поета - це холодна північ біля полярного кола).

Очевидно, що, увівши до заголовка повісті символічний образ птаха, Ю. Мушкетик хотів підкреслити піднесеність внутрішнього світу героїв, їхню легкість і відкритість. Крім того, у творі українського автора цей анімалістичний образ втілює життя, свободу й натхнення. Показово, що в першому виданні повісті замість нейтрального слова «птах» стояло - «лебідь» [див.: Мушкетик 1989]. На нашу думку, від такої заміни твір концептуально втратив, оскільки останнє слово-образ, як мінімум, викликає в українського читача асоціацію з віршем «Лебеді» (1928) Михайла Драй-Хмари, який, до речі, неокласик написав після перекладу сонету «Лебідь» («Суgne», 1885) Стефана Малларме. Утім, алюзійне поле цього образу може бути значно ширшим i включати оперу «Лоенгрін» («Lohengrin», перша постановка відбулася у 1850 р.) Ріхарда Вагнера, балет «Лебедине озеро» (прем’єра відбулася 1877 р.) Петра Чайковського, картину «Лебеді, відображені в слонах» («Cisnes que se reflejan como elefantes», 1937) Сальвадора Далі тощо.

Однак у контексті поетики назви повісті Ю. Мушкетика важливий інший момент, а саме те, що образ лебедя репрезентовано у «Скорботних елегіях» Овідія: «Наче той лебідь, щуо з сил опавщи при хвилях Каїстра, / Кажуть, загибель свою тужно оспівує сам, / Так от $i$ я, кого кинули ген на берег сарматський, / Дбаю, щуоб похорон мій без голосіння не був» («С.», V, I, 11-14) [Овідій 1999:251]. Отже, слово-образ «лебідь» могло би слугувати важливим 
елементом формування читацьких сподівань i первинних інтерпретацій $\mathrm{y}$ повісті Ю. Мушкетика. Однак автор відмовився від останнього, додатково завуалювавши зміст твору нейтральною лексемою.

Отже, заголовки романів «Останній світ» К. Рансмайра, «Скандал в імператорському сімействі» В. Чемериса та повісті «Літній птах на зимовому березі» Ю. Мушкетика відзначаються наявністю закодованого змісту, повнота висвітлення якого залежить від інтерпретаційної компетентності реципієнта. На відміну від інших текстів Овідіани, в назві твору «Овідій Назон - поет» Я. Бохенського немає вираженого імпліцитного змісту. Однак це не применшує смислового навантаження роману, оскільки ім'я героя, винесене в заголовок, передбачає відтворення в свідомості читача конкретної соціально-історичної доби, виразником якої є ця постать. Насамкінець зауважимо, що назва твору є первинним елементом його сприйняття, водночас відкриваючи простір для інших смислових вимірів, які становлять перспективу наших подальших досліджень.

\section{БІБЛІОГРАФІЯ}

Бабичева 2000 - Бабичева Ю. В. Поэтика заглавия / Ю. В. Бабичева // Вестник ТГПУ. Серия : Гуманитарные науки (Филология). - 2000. - Вып. 6. C. 61-64.

Балух 2005 - Балух В. О. Історія Стародавнього Риму : курс лекцій / В. О. Балух, В. П. Коцур. - Чернівці : Книги ХХІ, 2005. - 680 с.

Гундорова 2005 - Гундорова Т. І. Ядерний дискурс, або Література після Чорнобиля / Т. І. Гундорова // Післячорнобильська бібліотека : Український літературний постмодернізм. - К. : Критика, 2005. - С. 11-20.

Копистянська 2012 - Копистянська Н. Х. Соціально-історичний хронотоп / Нонна Хомівна Копистянська // Час і простір у мистецтві слова : [монографія]. - Львів : ПАІС, 2012. - Розд. 5. - С. 161-200.

Кржижановский 2006 - Кржижановский С. Д. Поэтика заглавий / Сигизмунд Доминикович Кржижановский // Собрание сочинений : [в 6 т.]. - 
СПб. : Symposium, 2001. - Т. 4: Поэтика заглавий ; Философия о театре ; Страны, которых нет ; Фрагменты о Шекспире ; Искусство эпиграфа (Пушкин). Драматургические приемы Бернарда Шоу. - 2006. - С. 7-42.

Мушкетик 1989 - Мушкетик Ю. Літній лебідь на зимовому березі : [повість] / Юрій Мушкетик // Вітчизна. - 1989. - № 1. - С. 16-68.

Петречко 2014 - Петречко О. Август, Гай Юлій Цезар Октавіан / Олег Петречко // Лексикон античної словесності / [за ред. М. Борецького, В. Зварича]. - Дрогобич : Коло, 2014. - С. 23-24.

Овідій 1999 - Публій Овідій Назон. Любовні елегії ; Мистецтво кохання ; Скорботні елегії / Публій Овідій Назон ; [пер. 3 латини А. Содомори ; передм. та комент. А. Содомори]. - К. : Основи, 1999. - 299 с.

Рансмайр 1994 - Рансмайр К. Останній світ : роман / Крістоф Рансмайр ; [пер. 3 нім. О. Логвиненко ; післямова Л. Цибенко]. - К. : Основи, 1994. - 206 с.

Челецька 2007 - Челецька М. М. Номеносфера поезії Івана Франка (поетика заголовків, присвят, епіграфів) / Мар'яна Маркіянівна Челецька. Львів : Львівське відділення Інституту літератури ім. Т. Г. Шевченка НАН України, 2007. - 304 с. - (Франкознавча серія. Вип. 9).

Чемерис 1988 - Чемерис В. Л. Скандал в імператорському сімействі : [історичний роман] / Валентин Лукич Чемерис. - К. : Рад. письменник, 1988. $415 \mathrm{c}$.

Шопенгауэр 2009 - Шопенгауэр А. О писательстве и о слоге / Артур Шопенгауэр ; [пер. с нем. Д. Н. Цертелева]. - изд. 2-е. - М. : Книжный дом «ЛИБРОКОМ», 2009. - 72 с.

Zaworska - Zaworska H. Boski Nazo [Źródło elektroniczne] / Helena Zaworska. - Tryb dostępu do dokumentu : http://jacekbochenski.blox.pl/html/13107 21,262146,21.html?548673. 